\title{
Toxicity of arsenic (As) on seed germination of sunflower (Helianthus annuus L.)
}

\author{
Muhammad Asif Imran ${ }^{1}$, Muhammad Nawaz $\mathrm{Ch}^{1}$, Rass Masood Khan ${ }^{2}$, Zulfiqar $\mathrm{Ali}^{1,3}$ and \\ Tariq Mahmood ${ }^{3 *}$
}

\author{
${ }^{1}$ College of Earth and Environmental Sciences, University of the Punjab, Lahore, Pakistan. \\ ${ }^{2}$ Department of Botany, University of the Punjab, Lahore, Pakistan. \\ ${ }^{3}$ Nano Science and Catalysis Division, National Centre for Physics, Quaid-i-Azam University, Islamabad 45320, \\ Pakistan.
}

Accepted 19 April, 2013

\begin{abstract}
The effect of different levels $(2,4,6,8$ and $10 \mathrm{mg} / \mathrm{L}$ ) of arsenic (as sodium arsenate and sodium arsenite) on germination percentage, mean germination time, days to $50 \%$ germination, plumule and radicle length and seedling vigour index of four sunflower cultivars (FH-331, FH-385, FH-405 and FH415) was determined under laboratory conditions. Germination percentage was gradually decreased with the increase in arsenic concentration in case of all sunflower cultivars. Low concentrations ( 2 and $4 \mathrm{mg} / \mathrm{L}$ arsenic) increased while higher concentrations $(6,8$ and $10 \mathrm{mg} / \mathrm{L}$ arsenic) posed stress and caused reduction in plumule and radicle length $(\mathrm{mm})$ of seedlings as compared to control. Out of all the four sunflower cultivars, $\mathrm{H} 1$ (FH-331) proved the most sensitive one by giving least values for plumule length, radicle length and seedling vigour index as observed during the course of this experiment.
\end{abstract}

Key words: Sodium arsenate, sodium arsenite, sunflower, seed germination, seedling growth.

\section{INTRODUCTION}

Environmental pollution has been proved to be one of byproducts of industrial revolution and modern technology strengthened by over population and mismanagement of resources. All metals are natural constituents of our environment and some of them are essentially required as micro-nutrients (Taiz and Zeiger, 2006). Arsenic (As) a ubiquitous, carcinogenic trace metalloid (Pigna et al., 2009) found in virtually all environmental media (Fitz and Wenzel, 2002). Arsenic exists in the environment in various organic and inorganic forms (species) (Mandal et al., 2011). The most important inorganic species are arsenate $\left(\mathrm{As}^{5+}\right)$ and arsenite $\left(\mathrm{As}^{3+}\right)$. Its toxicity to plants depends on its valence state. Due to greater cellular uptake, $\mathrm{As}^{+3}$ is 60 times more soluble, mobile and toxic than $\mathrm{As}^{5+}$ (Giri and Patel, 2012). Arsenic concentration varies in the environment, from less than $1 \mathrm{mg} / \mathrm{kg}$ to as high as $100,000 \mathrm{mg} / \mathrm{kg}$ in soil (Liu et al., 2002) and one in every 60 people on the planet is living in an area where $50 \mu \mathrm{g} / \mathrm{L}$ or above of arsenic is in ground water (Tibbetts, 2000).

Arsenic contamination may be greater in soils naturally or by human activities through the use of various arsenical pesticides, wood preservatives, industrial wastes and growth promoters for plants and animals (Williams et al., 2005). Irrigation through As-laden ground water in Asia also causes bioaccumulation of As (Dittmar et al., 2010). To evaluate the possible health risk to humans consuming crops irrigated with As contaminated water, information is needed regarding the soil-to-plant transportation of As and to minimize the accumulation of 
As in plants consumed directly by humans, farm animals or wildlife (Meharg and Hartley-Whitaker, 2002).

In plants, arsenic is accumulated according to tolerance (Zhong et al., 2011) mainly in the root system, to various degrees in the above ground organs, depending upon its translocation (Mei et al., 2012). The metal tolerance potential of different plant species varies greatly between different species as well as among different genotypes of a same species (Ahmad et al., 2009). Large number of studies indicated that low concentrations of As stimulated the growth of plants but excessive As did harm to plants (Han et al., 2003). Seed germination and seedling growth of wheat were stimulated at low and inhibited at high (5 to $20 \mathrm{mg} / \mathrm{kg}$ soil) arsenic concentrations (Zhang et al., 2002).

Sunflower (Helianthus annuus L.) being one of newly added crop to human food chain, is cultivated in Pakistan on 32539 ha with average yield of $816.4 \mathrm{~kg}$ per ha and average annual production of 612530 tones (GOP, 2012) fulfills the cooking oil requirements of the country population along with other oil-seed crops. The objective of this study was to evaluate the intra-specific/cultivar comparisons for arsenic tolerance in four sunflower hybrids at the seed germination stage which is considered more vulnerable to any stress than latter growth stages of most plant species.

\section{MATERIALS AND METHODS}

\section{Seeds and metal salts}

Dry, healthy and uniform sized achenes (seeds) of four sunflower cultivars viz. $\mathrm{FH}-331, \mathrm{FH}-385, \mathrm{FH}-405$ and $\mathrm{FH}-415$ were collected from the Oil Seed Department of Ayub Agriculture Research Institute (AARI) Faisalabad, Pakistan. Seeds were surface sterilized using $5 \%$ sodium hypochlorite solution for five minutes and rinsed thrice with distilled water to prevent any kind of fungal contamination. Two salts of arsenic viz. sodium arsenate $\left(\mathrm{Na}_{2} \mathrm{HAsO}_{4} .7 \mathrm{H}_{2} \mathrm{O}\right)$ and sodium arsenite $\left(\mathrm{NaAsO}_{2}\right)$ of Sigma Aldrich, Japan, were used for arsenic treatments application. Twenty seeds were placed in each Petri plate of $9 \mathrm{~cm}$ diameter lined with double layered filter paper (Whattman No. 2).

\section{Treatments application}

Five levels (2, 4, 6, 8 and $10 \mathrm{mg} / \mathrm{L})$ of both arsenic salts, sodium arsenate $\left(\mathrm{Na}_{2} \mathrm{HAsO}_{4} .7 \mathrm{H}_{2} \mathrm{O}\right)$ and sodium arsenite $\left(\mathrm{NaAsO}_{2}\right)$ were formulated in Hoagland's nutrient solution for the treatment application and one without any arsenic application was considered as control which were provided only nutrient solution. Freshly prepared $10 \mathrm{ml}$ of treatment solution was applied to respective petriplate after wasting the previous solution daily. The petriplates were kept in climatic room under controlled conditions of temperature ( $25{ }^{\circ} \mathrm{C} \pm 2 \stackrel{\circ}{\circ}$ ), relative humidity (65\%) and continuous white fluorescent light (PAR $\left.300 \mu \mathrm{mol} \mathrm{m} \mathrm{m}^{-2} \mathrm{~s}^{-1}\right)$. Number of germinated seeds was counted daily and data were recorded after every $12 \mathrm{~h}$ for fourteen days regularly. A seed was considered as germinated when $5 \mathrm{~mm}$ of radicle had emerged out of seed coat. Following seed germination parameters were recorded. Germination percentage was measured according to the formula given by Tanveer et al. (2010).
Germination percentage $=($ Germinated seeds $\div$ Total seeds $) \times 100$

Mean germination time was calculated in days according to the equation given by Dezfuli et al. (2008).

$M G T=\sum D n \div \sum n$

Where $\mathrm{n}$ is the number of seeds germinated on day $\mathrm{D}$, and $\mathrm{D}$ is number of days counted from the beginning of germination.

The time to $50 \%$ germination $\left(T_{50}\right)$ was calculated according to the following formula modified by Farooq et al. (2005; 2006).

$T_{50}=t i+[\{(N / 2)-n i\}(t j-t i)] \div(n j-n i)$

Where $\mathrm{N}$ is the final number of germinated seeds and ni, nj are cumulative number of seeds germinated by adjacent counts at times ti and tj where $n i<N / 2<n j$.

Total germinated seeds were collected after fourteen days and plumule and radicle were carefully detached for the estimation of plumule length and radicle length in milli meters with the help of a scale. Vigour index for seedling was calculated as the formula given by Cokkizgin and Cokkizgin (2010).

Seedling vigour index $(S V I)=[M P L+M R L] \times G P$

Where $M P L=$ Mean plumule length, $M R L=$ mean radicle length, $\mathrm{GP}=$ germination percentage. Experiment was laid out in completely randomized design (CRD) with three replicates. The data regarding all seed germination parameters was subjected to a two-way analysis of variance (ANOVA) with the help of COSTAT computer software (Cohort software, 2003, Monterey, California) and to compare significance of interaction means, least significance difference values (LSD) were also calculated.

\section{RESULTS AND DISCUSSION}

Two way analysis of variance (ANOVA) for all parameters revealed significant differences for sunflower hybrids, different treatments (except for Mean Germination Time) and interaction of hybrids and treatments for both sodium arsenate and sodium arsenite used for arsenic treatments application (Table 1).

\section{Germination Percentage (G \%age)}

Highly significant differences were found among different arsenic treatments and sunflower hybrids (Table 1) for germination percentage. Considerable decrease in germination percentage was recorded with increasing level of arsenic in all the four sunflower cultivars used in this experiment as stated by Ahmad et al. (2009) that higher concentrations of heavy metals suppresses the seed germination parameters. Out of different treatments T5 (10 mg/L As) affected most severely to all seed germination parameters studied. Sodium arsenite posed more stress on germination percentage, as inorganic $A s^{(I I I)}$ is more toxic than $\mathrm{As}^{(\mathrm{V})}$ (Winkel et al., 2008) and least value $(55 \%)$ was calculated in treatment with 10 $\mathrm{mg} / \mathrm{L}$ arsenic applied as sodium arsenite (Figure 1 and Table 2), whereas with same concentration of sodium 


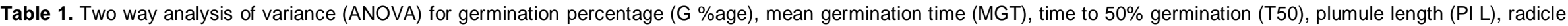
length (RI L) and seedling vigour index (SVI) of sunflower cultivars.

\begin{tabular}{|c|c|c|c|c|c|c|c|c|c|c|c|c|c|}
\hline \multirow[b]{3}{*}{ Source } & \multirow[b]{3}{*}{ DF } & \multicolumn{12}{|c|}{ Mean square } \\
\hline & & \multicolumn{2}{|c|}{ Germination percentage } & \multicolumn{2}{|c|}{ M G T } & \multicolumn{2}{|c|}{ T 50} & \multicolumn{2}{|c|}{ PIL } & \multicolumn{2}{|c|}{ RI L } & \multicolumn{2}{|c|}{ S VI } \\
\hline & & $\begin{array}{c}\text { Sodium } \\
\text { arsenate }\end{array}$ & $\begin{array}{l}\text { Sodium } \\
\text { arsenite }\end{array}$ & $\begin{array}{c}\text { Sodium } \\
\text { arsenate }\end{array}$ & $\begin{array}{c}\text { Sodium } \\
\text { arsenite }\end{array}$ & $\begin{array}{c}\text { Sodium } \\
\text { arsenate }\end{array}$ & $\begin{array}{c}\text { Sodium } \\
\text { arsenite }\end{array}$ & $\begin{array}{c}\text { Sodium } \\
\text { arsenate }\end{array}$ & $\begin{array}{c}\text { Sodium } \\
\text { arsenite }\end{array}$ & $\begin{array}{c}\text { Sodium } \\
\text { arsenate }\end{array}$ & $\begin{array}{c}\text { Sodium } \\
\text { arsenite }\end{array}$ & $\begin{array}{c}\text { Sodium } \\
\text { arsenate }\end{array}$ & $\begin{array}{l}\text { Sodium } \\
\text { arsenite }\end{array}$ \\
\hline Hybrids $(\mathrm{H})$ & 3 & $497.22^{* *}$ & $536.11^{* *}$ & $33.93^{* *}$ & $26.39^{* *}$ & $10.04^{* *}$ & $17.41^{* *}$ & $307.90^{* *}$ & $467.41^{* *}$ & $441.56^{* *}$ & $491.76^{* \star}$ & $7533128^{* *}$ & $8406116.4^{* *}$ \\
\hline Treatments $(T)$ & 5 & $554.72^{* *}$ & $2064.72^{* *}$ & $0.72^{\mathrm{ns}}$ & $1.16^{\mathrm{ns}}$ & $1.21^{* *}$ & $1.13^{\mathrm{ns}}$ & $75.22^{* *}$ & $137.91^{* *}$ & $90.70^{* *}$ & $139.52^{* *}$ & $4639275.5^{\star *}$ & $9274712^{* *}$ \\
\hline $\mathrm{H} \times \mathrm{T}$ Interaction & 15 & $170.83^{* *}$ & $181.94^{* *}$ & $1.02^{* *}$ & $0.54 \mathrm{~ns}$ & $1.04^{* *}$ & $1.13^{*}$ & $13.97^{\star *}$ & $7.12^{\mathrm{ns}}$ & $15.93^{* *}$ & $12.62 \mathrm{~ns}$ & $770738.76^{\star *}$ & $628847.1 \mathrm{~ns}$ \\
\hline Error & 48 & 53.12 & 68.75 & 0.41 & 0.49 & 0.31 & 0.53 & 5.53 & 6.48 & 5.25 & 9.88 & 264354.51 & 340110.31 \\
\hline \multirow{2}{*}{ CV (\%) Mean } & & 8.631 & 10.85 & 12.825 & 14.96 & 13.338 & 16.92 & 12.207 & 12.68 & 9.909 & 13.39 & 14.402 & 17.33 \\
\hline & & 84.44 & 76.39 & 5.023 & 4.68 & 4.158 & 4.29 & 19.274 & 20.07 & 23.13 & 23.47 & 3569.96 & 3365.39 \\
\hline
\end{tabular}

Significance Level: $0.05,{ }^{* *}$ Highly significant, ${ }^{\text {ns }}$ Non significant.

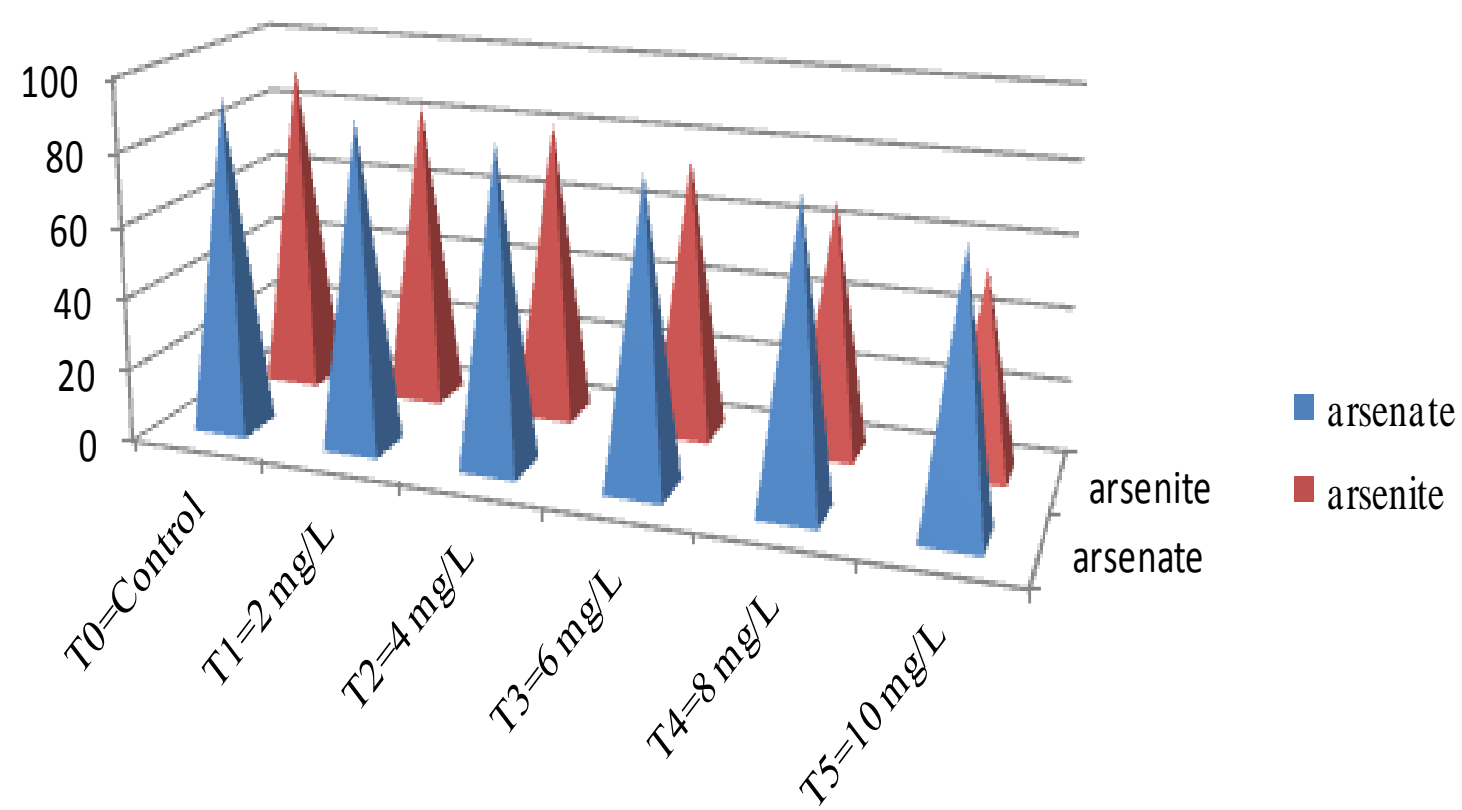

Figure 1. Effect of arsenicals on germination percentage (G \%age) of sunflower. 
Table 2. Means of arsenical (sodium arsenate and sodium arsenite) treatments for all parameters.

\begin{tabular}{|c|c|c|c|c|c|c|c|c|c|c|c|c|}
\hline \multirow[b]{2}{*}{ Treatments } & \multicolumn{2}{|c|}{ Germination percentage } & \multicolumn{2}{|c|}{ M G T } & \multicolumn{2}{|c|}{ T 50} & \multicolumn{2}{|c|}{ PI L } & \multicolumn{2}{|c|}{ Rd L } & \multicolumn{2}{|c|}{ S VI } \\
\hline & $\begin{array}{c}\text { Sodium } \\
\text { arsenate }\end{array}$ & $\begin{array}{l}\text { Sodium } \\
\text { arsenite }\end{array}$ & $\begin{array}{c}\text { Sodium } \\
\text { arsenate }\end{array}$ & $\begin{array}{c}\text { Sodium } \\
\text { arsenite }\end{array}$ & $\begin{array}{c}\text { Sodium } \\
\text { arsenate }\end{array}$ & $\begin{array}{l}\text { Sodium } \\
\text { arsenite }\end{array}$ & $\begin{array}{c}\text { Sodium } \\
\text { arsenate }\end{array}$ & $\begin{array}{l}\text { Sodium } \\
\text { arsenite }\end{array}$ & $\begin{array}{c}\text { Sodium } \\
\text { arsenate }\end{array}$ & $\begin{array}{c}\text { Sodium } \\
\text { arsenite }\end{array}$ & $\begin{array}{c}\text { Sodium } \\
\text { arsenate }\end{array}$ & $\begin{array}{l}\begin{array}{c}\text { Sodium } \\
\text { arsenite }\end{array} \\
\end{array}$ \\
\hline T0- Control & $92.08^{a}$ & $92.08^{a}$ & $5.02^{\mathrm{ab}}$ & $5.02^{\mathrm{a}}$ & $4.50^{\mathrm{a}}$ & $4.50^{\mathrm{ab}}$ & $17.61^{\text {de }}$ & $17.62^{c}$ & $22.5^{c}$ & $22.5^{b}$ & $3670.5^{\mathrm{bc}}$ & $3670.5^{b c}$ \\
\hline T1- 2 mg/L & $90^{a}$ & $84.16^{b}$ & $5.20^{\mathrm{ab}}$ & $4.63^{\mathrm{ab}}$ & $4.23^{\mathrm{ab}}$ & $3.97^{b}$ & $19.55^{b c}$ & $22.97^{a}$ & $23.58^{b c}$ & $26.53^{a}$ & $3908.67 \mathrm{ab}$ & $4155.3^{a}$ \\
\hline $\mathrm{T} 2-4$ mg/L & $87.08^{\mathrm{ab}}$ & $82.5^{\mathrm{bc}}$ & $4.76^{\mathrm{ab}}$ & $4.16^{b}$ & $3.73^{c}$ & $3.96^{b}$ & $22.94^{a}$ & $23.07^{a}$ & $26.62^{a}$ & $25.06^{a b}$ & $4296.96^{a}$ & $4098.62^{\mathrm{ab}}$ \\
\hline T3- 6 mg/L & $82.5^{b}$ & $75.83^{c}$ & $4.68^{b}$ & $4.62^{\mathrm{ab}}$ & $4.01 \mathrm{bc}$ & $4.37 \mathrm{ab}$ & $21.1 \mathrm{ab}$ & $21.96 \mathrm{ab}$ & $25.11^{a b}$ & $25.11 \mathrm{ab}$ & $3732.25^{b c}$ & $3533.96^{c}$ \\
\hline $\mathrm{T} 4-8 \mathrm{mg} / \mathrm{L}$ & $81.67^{b}$ & $68.75^{d}$ & $5.28^{a}$ & $4.65^{\mathrm{ab}}$ & $3.94^{b c}$ & $4.19^{a b}$ & $18.48^{\mathrm{cd}}$ & $20.25^{b}$ & $22.37^{c}$ & $22.81^{b}$ & $3336.33^{c}$ & $2909.04^{d}$ \\
\hline $\mathrm{T} 5-10 \mathrm{mg} / \mathrm{L}$ & $73.33^{c}$ & $55^{\mathrm{e}}$ & $5.18^{\mathrm{ab}}$ & $4.98^{\mathrm{a}}$ & $4.52^{\mathrm{a}}$ & $4.74^{\mathrm{a}}$ & $15.94 \mathrm{e}$ & $14.56^{d}$ & $18.61^{d}$ & $17.47^{c}$ & $2475.08^{d}$ & $1824.92^{\mathrm{e}}$ \\
\hline LSD & 5.98 & 6.81 & 0.52 & 0.57 & 0.37 & 0.59 & 1.93 & 2.08 & 1.88 & 2.58 & 422.04 & 478.70 \\
\hline
\end{tabular}

Different letters indicate significant differences at 0.05 levels.

Table 3. Means of sunflower cultivars for all parameters

\begin{tabular}{|c|c|c|c|c|c|c|c|c|c|c|c|c|}
\hline \multirow[b]{2}{*}{$\begin{array}{l}\text { Sunflower } \\
\text { hybrids }\end{array}$} & \multicolumn{2}{|c|}{ Germination percentage } & \multicolumn{2}{|c|}{ M G T } & \multicolumn{2}{|c|}{ T 50} & \multicolumn{2}{|c|}{ PI L } & \multicolumn{2}{|c|}{ Rd L } & \multicolumn{2}{|c|}{ S VI } \\
\hline & $\begin{array}{c}\text { Sodium } \\
\text { arsenate }\end{array}$ & $\begin{array}{c}\text { Sodium } \\
\text { arsenite }\end{array}$ & $\begin{array}{c}\text { Sodium } \\
\text { arsenate }\end{array}$ & $\begin{array}{c}\text { Sodium } \\
\text { arsenite }\end{array}$ & $\begin{array}{c}\text { Sodium } \\
\text { arsenate }\end{array}$ & $\begin{array}{c}\text { Sodium } \\
\text { arsenite }\end{array}$ & $\begin{array}{c}\text { Sodium } \\
\text { arsenate }\end{array}$ & $\begin{array}{c}\text { Sodium } \\
\text { arsenite }\end{array}$ & $\begin{array}{c}\text { Sodium } \\
\text { arsenate }\end{array}$ & $\begin{array}{c}\text { Sodium } \\
\text { arsenite }\end{array}$ & $\begin{array}{c}\text { Sodium } \\
\text { arsenate }\end{array}$ & $\begin{array}{c}\text { Sodium } \\
\text { arsenite }\end{array}$ \\
\hline $\mathrm{H} 1: \mathrm{FH}-331$ & $90.56^{a}$ & $75.83^{b}$ & $6.67^{\mathrm{a}}$ & $6.31^{\mathrm{a}}$ & $4.41^{b}$ & $5.54^{\mathrm{a}}$ & $13.2^{c}$ & $13.65^{d}$ & $15.88^{c}$ & $17.01^{c}$ & $2639.83^{c}$ & $2415.36^{c}$ \\
\hline H2: FH-385 & $83.06^{\mathrm{b}}$ & $71.67^{b}$ & $3.46^{d}$ & $3.61^{c}$ & $3.11^{c}$ & $3.31^{c}$ & $22.15^{a}$ & $22.95^{b}$ & $26.94^{a}$ & $27.35^{a}$ & $4120.31^{a}$ & $3623.83^{b}$ \\
\hline H3: FH-405 & $78.06^{c}$ & $73.89 \mathrm{~b}$ & $4.47^{c}$ & $3.94^{c}$ & $4.24^{b}$ & $3.74^{c}$ & $21.59^{a b}$ & $25.17^{a}$ & $25.37^{b}$ & $28.07^{a}$ & $3672.17^{b}$ & $4021.44^{a}$ \\
\hline H4: FH-415 & $86.11^{a b}$ & $84.16^{a}$ & $5.48^{b}$ & $4.86^{\mathrm{b}}$ & $4.88^{a}$ & $4.56^{b}$ & $20.15^{b}$ & $18.51^{\mathrm{c}}$ & $24.35^{b}$ & $21.45^{b}$ & $3847.56^{\mathrm{ab}}$ & $3400.94^{b}$ \\
\hline LSD & 4.89 & 5.56 & 0.43 & 0.47 & 0.3 & 0.48 & 1.58 & 1.71 & 1.54 & 2.11 & 344.59 & 390.86 \\
\hline
\end{tabular}

Different letters represent significant difference at 0.05 levels.

arsenate $73.33 \%$ germination percentage value was recorded. Maximum value $(92.08 \%)$ was noted in control which was devoid of any arsenic application. Sunflower hybrid type $\mathrm{H} 1$ (FH-331) showed best germination percentage with $90.56 \%$ when arsenic was applied as sodium arsenate while with sodium arsenite germination percentage was reduced to $75.83 \%$. The minimum germination percentage $71.56 \%$ was recorded in $\mathrm{FH}-385(\mathrm{H} 2)$. Achenes of $\mathrm{H} 4(\mathrm{FH}-415)$ responded in a same way (Table 3 ) with both kinds of arsenic salts in case of germination percentage parameter.

\section{Mean germination time (MGT)}

Two way analysis of variance (ANOVA) revealed 


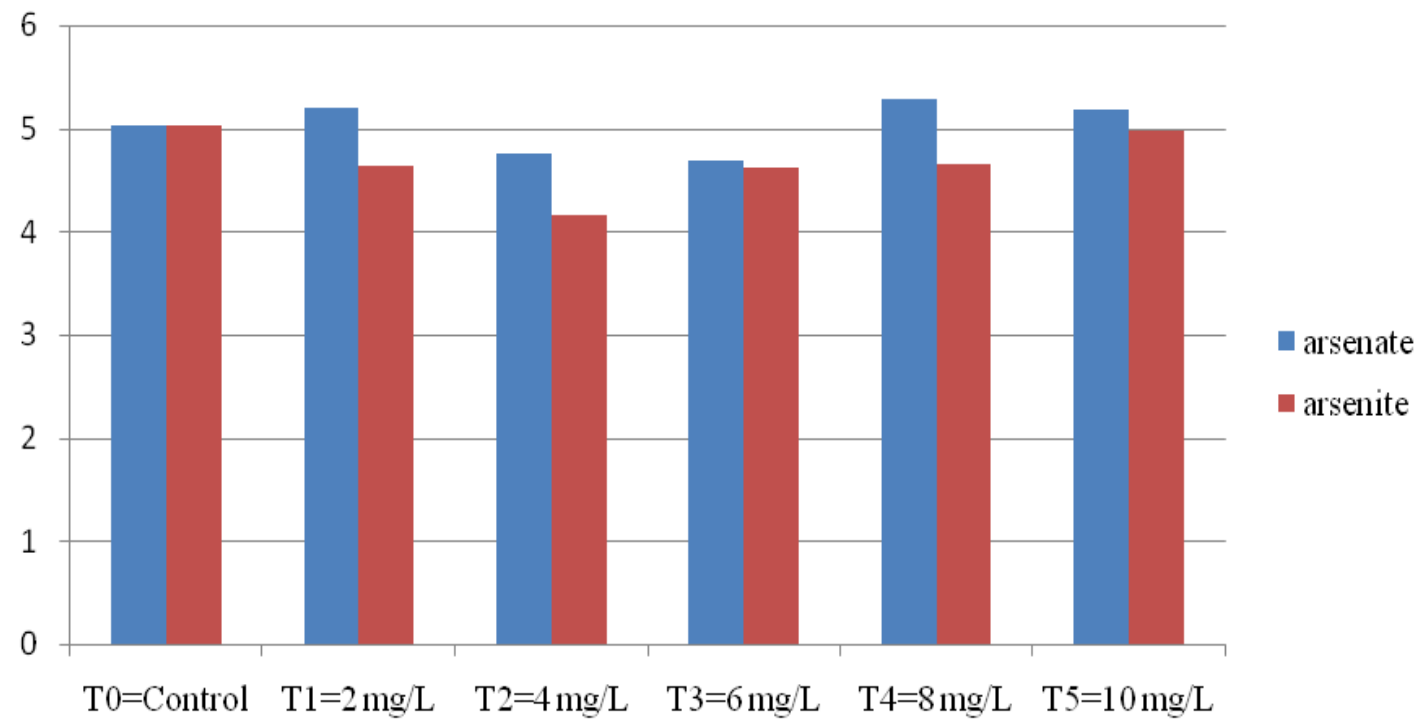

Figure 2. Effect of arsenicals on mean germination time of sunflower.

significant differences for different hybrids in case of both salts of arsenic but there were non-significant differences for various treatments (Table 1 and Figure 2) whereas interaction of hybrids into treatments revealed significant differences for sodium arsenate while non-significant differences for sodium arsenite. Achenes or seeds belonging to treatment $\mathrm{T} 4$ (8 $\mathrm{mg} / \mathrm{L}$ arsenic) showed maximum value (5.28) for mean germination time (MGT) as in Table 2, while out of different cultivars $\mathrm{H} 2(\mathrm{FH}-385)$ showed minimum MGT value (3.46) and $\mathrm{H} 1(\mathrm{FH}-331)$ showed maximum MGT value (6.67). Both of arsenic salts showed similar effects on mean germination time for sunflower seeds (Tables 2 and 3) as low doses caused the seeds to germinate early as compared to control while high concentration of arsenic salts caused a little bit delay in germination of sunflower seeds (Gulz et al., 2005) with higher MGT value.

\section{Time to $50 \%$ germination $\left(T_{50}\right)$}

Significant differences were found for different sunflower hybrids/cultivars in case of both sodium salts of arsenic whereas in case of treatments of arsenic, sodium arsenite treatments showed non-significant differences. The interaction between treatments and hybrids also showed significant differences (Table 1). Out of different treatments T0 (control) showed same value (4.50 days) as time to $50 \%$ germination for both of salts used. Treatment T2 (4 mg/L arsenic) of sodium arsenate gave the least value for days to $50 \%$ germination (Table 2 and Figure 3) which shows that low concentration of arsenic boasts up the rate of seed germination (Cheng et al., 2006) but high concentration of arsenic $10 \mathrm{mg} / \mathrm{L}$ arsenic in both forms of arsenic slows down the rate of seed germination ( $\mathrm{Li}$ et al., 2007) by giving maximum value (4.52 and 4.74 for sodium arsenate and arsenite, respectively) for days to $50 \%$ germination.

\section{Plumule length (mm)}

Different sunflower hybrids and various treatments of arsenic as well as interaction of hybrid into treatments showed significant differences except the interaction value in case of sodium arsenite application as inferred from the analysis of variance (Table 1). Treatment means showed the maximum value $(23.07 \mathrm{~mm})$ in case of T2 (4 $\mathrm{mg} / \mathrm{L}$ arsenic) using sodium arsenite (Table 2 and Figure 4) which is $130.9 \%$ of control $(17.62 \mathrm{~mm})$. This reveals that low concentrations of arsenic increase the seedling growth up-to certain limit but after that more increase in concentration inhibits the seedling growth (Liu and Zhang, 2007; Geng et al., 2006) as least value (14.56 $\mathrm{mm}$ ) was recorded in highest concentration $(10 \mathrm{mg} / \mathrm{L})$ of sodium arsenite. Sunflower cultivars behaved differently (Table 3) in case of plumule length as out of different sunflower cultivars $\mathrm{H} 3$ (FH-405) gave maximum plumule length $(25.17 \mathrm{~mm})$ whereas least value $(13.2 \mathrm{~mm})$ was observed in $\mathrm{H} 1$ (FH-331).

\section{Radicle length ( $\mathrm{mm})$}

All the sunflower hybrids and different treatments of arsenic showed significant differences except for the treatment into hybrid interaction values which showed non-significant differences for sodium arsenite (Table 1). 


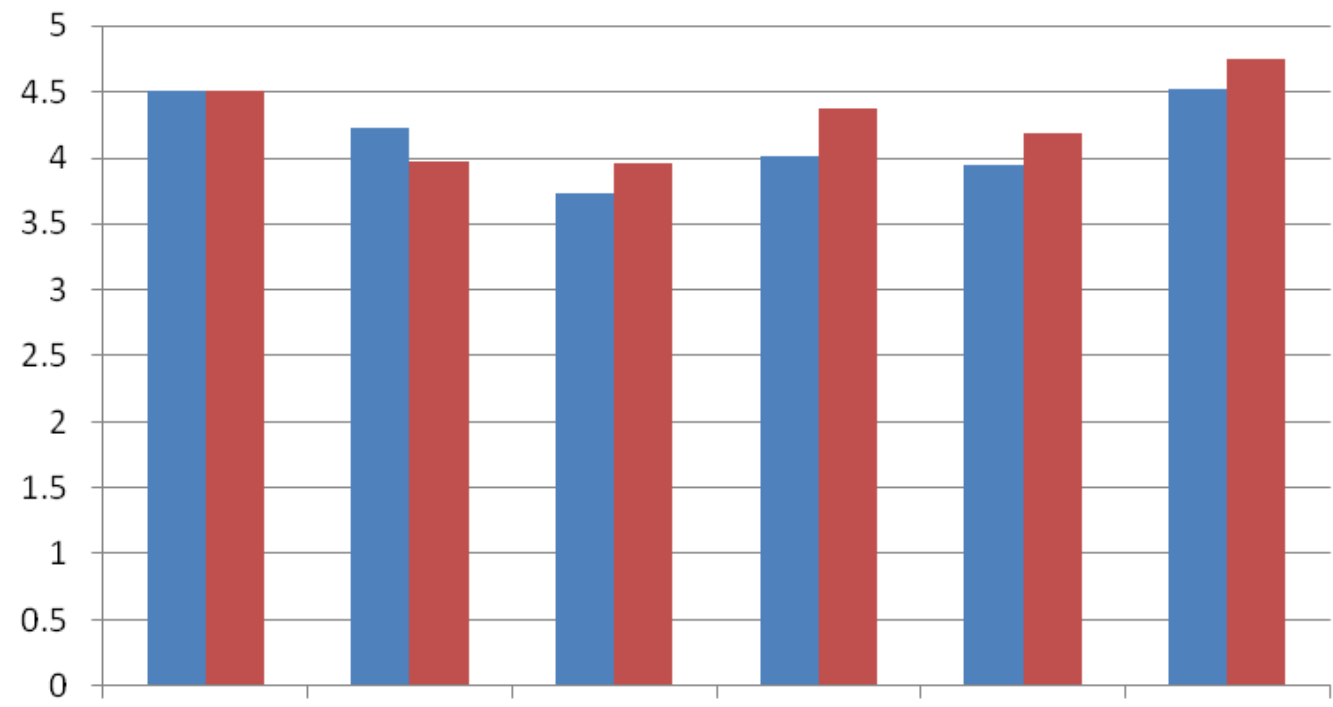

arsenate

arsenite

$\mathrm{T} 0=$ Control $\quad \mathrm{T} 1=2 \mathrm{mg} / \mathrm{L} \quad \mathrm{T} 2=4 \mathrm{mg} / \mathrm{L} \quad \mathrm{T} 3=6 \mathrm{mg} / \mathrm{L} \quad \mathrm{T} 4=8 \mathrm{mg} / \mathrm{L} \quad \mathrm{T} 5=10 \mathrm{mg} / \mathrm{L}$

Figure 3. Effect of arsenicals on time to $50 \%$ germination of sunflower.

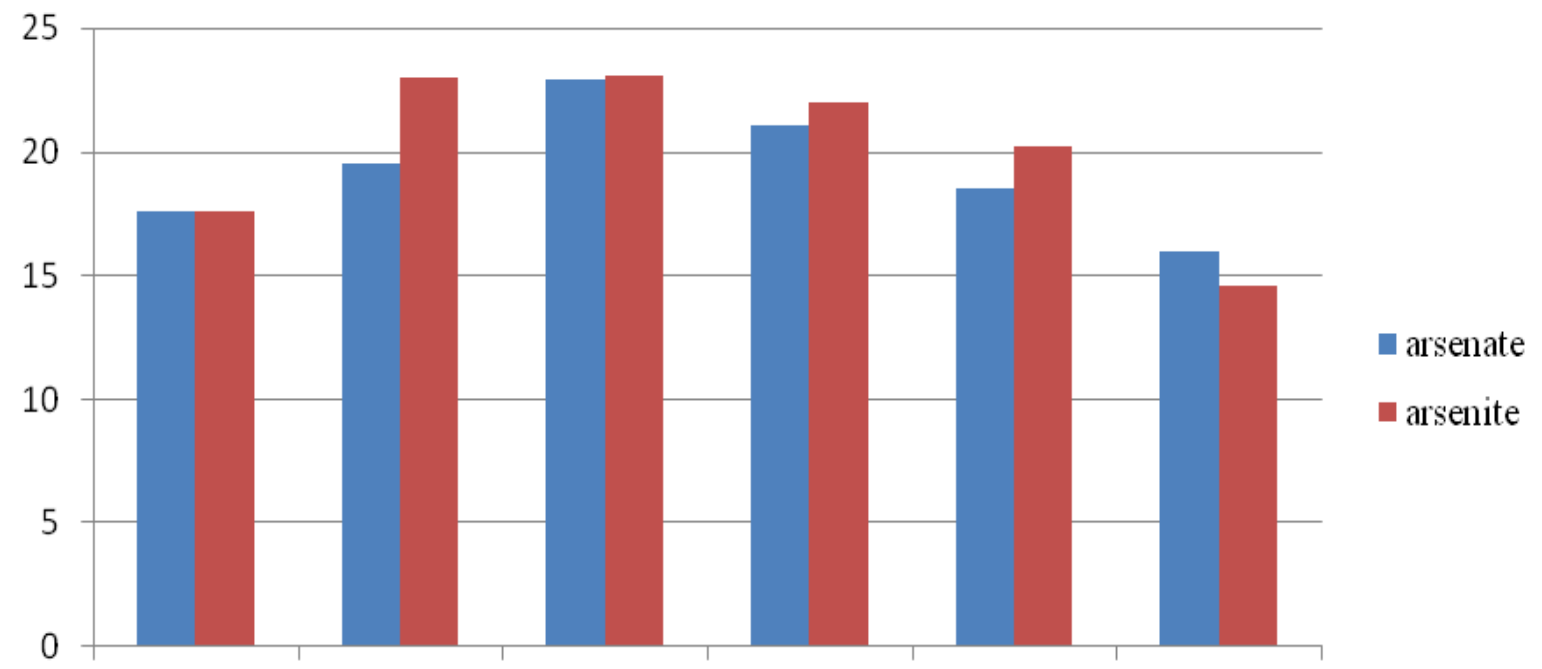

$\mathrm{T} 0=$ Control $\quad \mathrm{T} 1=2 \mathrm{mg} / \mathrm{L} \quad \mathrm{T} 2=4 \mathrm{mg} / \mathrm{L} \quad \mathrm{T} 3=6 \mathrm{mg} / \mathrm{L} \quad \mathrm{T} 4=8 \mathrm{mg} / \mathrm{L} \quad \mathrm{T} 5=10 \mathrm{mg} / \mathrm{L}$

Figure 4. Effect of arsenicals on plumule length of sunflower.

Highest mean value $(26.62 \mathrm{~mm})$ of radicle length was recorded in case of $\mathrm{T} 2$ (4 $\mathrm{mg} / \mathrm{L}$ arsenic) as sodium arsenate while the least value $(17.47 \mathrm{~mm})$ was observed in case of $\mathrm{T} 5(10 \mathrm{mg} / \mathrm{L}$ arsenic) as sodium arsenite (Table 2, Figure 5), proving that in low concentration arsenic promotes the seed germination but high concentrations of metal inhibits the growth of seedling by suppressing root or radicle growth (Lux et al., 2011). Out of different sunflower cultivars (Table 3 ) used in this experiment $\mathrm{H} 3(\mathrm{FH}-405)$ gave maximum radical length
(28.07 mm) while $\mathrm{H} 1$ (FH-415) gave least value (15.88 $\mathrm{mm})$.

\section{Seedling vigour index (SVI)}

Highly significant differences were given by two way analysis of variance (ANOVA) for sunflower cultivars and different arsenic treatments as well as interaction of hybrids into treatments except for interaction value in 


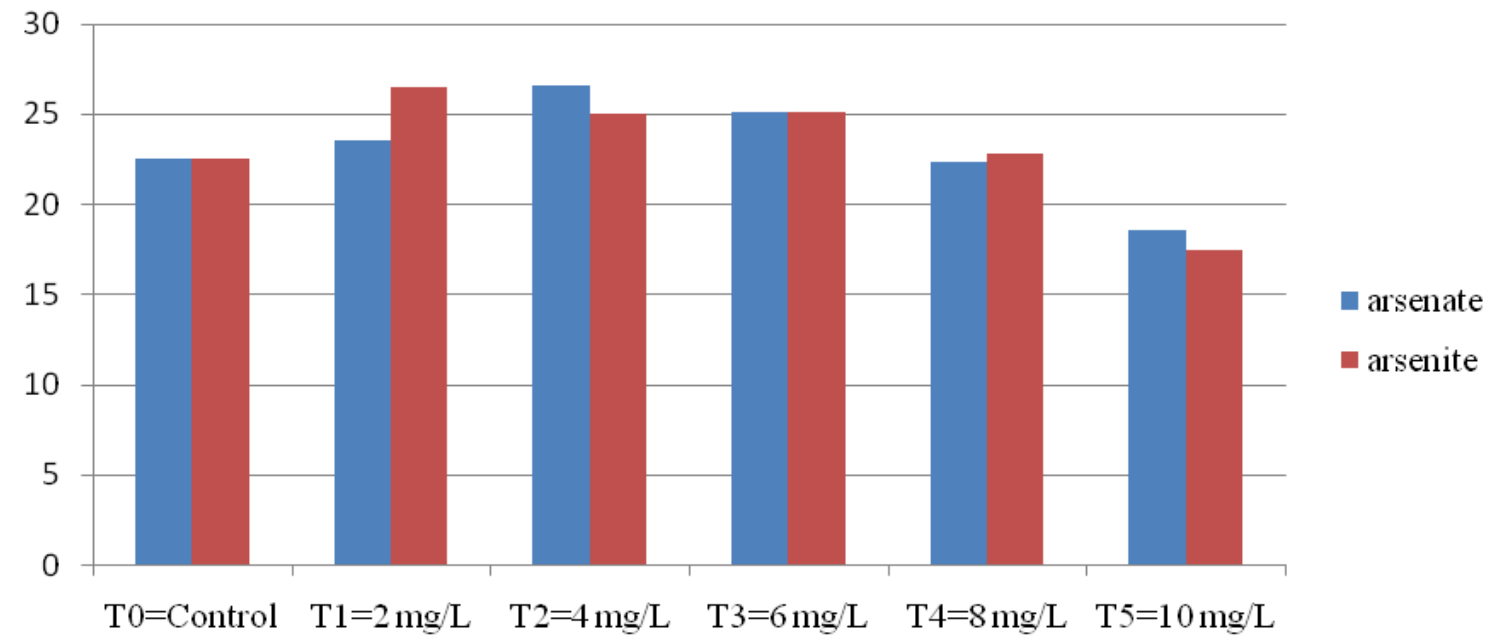

Figure 5. Effect of arsenicals on radicle length of sunflower achenes.

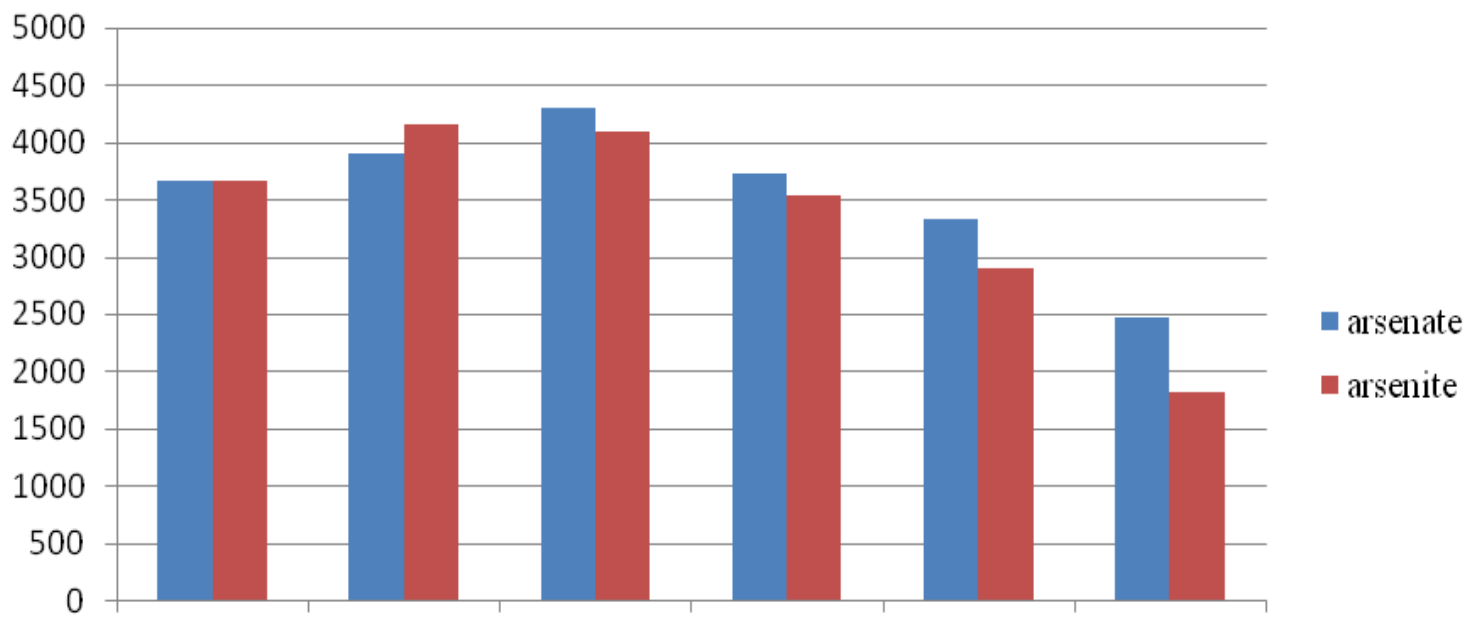

$\mathrm{T} 0=$ Control $\quad \mathrm{T} 1=2 \mathrm{mg} / \mathrm{L} \quad \mathrm{T} 2=4 \mathrm{mg} / \mathrm{L} \quad \mathrm{T} 3=6 \mathrm{mg} / \mathrm{L} \quad \mathrm{T} 4=8 \mathrm{mg} / \mathrm{L} \quad \mathrm{T} 5=10 \mathrm{mg} / \mathrm{L}$

Figure 6. Effect of arsenicals on seedling vigour index (SVI) of sunflower.

case of sodium arsenite which showed non-significant differences (Table 1). Maximum SVI value (4296.96) for treatment means was recorded in case of T2 $(4 \mathrm{mg} / \mathrm{L}$ arsenic) using sodium arsenate while T10 (10 mg/L arsenic) using sodium arsenite gave least value (1824.92) as shown in Table 2. Out of different sunflower cultivars, H2 (FH-385) gave highest SVI value (4120.31) while $\mathrm{H} 1$ (FH-331) gave least value (2415.36) of seedling vigour index (Table 3 and Figure 6).

\section{Conclusion}

It can be concluded that arsenic is non-essential to plants and higher concentrations (6,8 and $10 \mathrm{mg} / \mathrm{L}$ arsenic) of both inorganic arsenicals (arsenate as well as arsenite) posed a stress over all germination parameters observed during seed germination of four different sunflower cultivars, but arsenite $\left(\mathrm{As}^{3+}\right)$ posed more stressful effects than that of arsenate $\left(\mathrm{As}^{5+}\right)$ contamination. Low concentrations (2 and $4 \mathrm{mg} / \mathrm{L}$ arsenic), of both of arsenicals caused increase in plumule and radicle lengths of sunflower seedlings, as compared to control. Gradual decrease in germination percentage was observed with the increase in arsenic concentrations of both arsenic forms in case of all sunflower hybrids. $\mathrm{H} 1$ (FH-331) proved to be most sensitive for arsenic application by giving least values for plumule length, radicle length and seedling vigour index. Best seedling vigour index was recorded in sunflower cultivar 
$\mathrm{H} 2$ (FH-385), showing a little bit resistance to arsenic contamination.

\section{REFERENCES}

Ahmad MSA, Hussain M, Ashraf M, Ahmad R, Ashraf MY (2009). Effect of nickel on seed germ inability of some elite sunflower (Helianthus annuus L.) cultivars. Pak. J. Bot. 41(4):1871-1882.

Cheng W, Zhang G, Yao H, Wu W, Xu M (2006). Genotypic and Environmental variations in cadmium, chromium, arsenic, nickel and lead concentrations in rice grains. J. Zhejiang Uni. Sci. B. 7:565571.

Cokkizgin A, Cokkizgin $\mathrm{H}(2010)$. Effects of lead $\left(\mathrm{PbCl}_{2}\right)$ stress on germination of lentil (Lens culinaris Medic.) lines. Afr. J. Biotechnol. $9(50): 8608-8612$.

Dezfuli PM, Sharif-Zadeh F, Janmohammadi M (2008). Influence of priming techniques on seed germination behavior of maize inbred lines (Zea mays L.) ARPN. J. Agric. Biol. Sci. 3(3):22-25.

Dittmar J, Voegelin A, Maurer F, Roberts LC, Hug SJ, Saha GC, Ali MA, Badruzzaman ABM, Kretzschmar R (2010). Arsenic in soil and irrigation water affects arsenic uptake by rice: complementary insights from field and pot studies. Environ. Sci. Technol. 44:88428848.

Farooq M, Basra SMA, Hafeez K, Ahmad N (2005). Thermal hardening: a new seed vigor enhancement tool in rice. Acta. Botanica Sinica. 47:187-193.

Farooq M, Basra SMA, Hafeez-ur-Rehman, Mehmood T (2006). Germination and early seedling growth as affected by pre-sowing ethanol seed treatments in fine rice. Int. J. Agri. Biol. 8(1):19-22.

Fitz WJ, Wenzel WW (2002). Arsenic transformation in the soilrhizosphere-plant system: Fundamentals and potential application to phytoremediation. J. Biotechnol. 99:259-278.

Geng CN, Zhu YG, Tong YP, Smith SE, Smith FA (2006). Arsenate (As) uptake by and distribution in two cultivars of winter wheat (Triticum aestivum L.). Chemosphere 62:608-615.

Giri AK, Patel RK (2012). Phytoaccumulation potential and toxicity of arsenic ions by Eichhornia crassipes in hydroponic system. J. Bioremed. Biodegrad. 3:137.

GOP (Government of Pakistan) (2012). Agriculture Statistics of Pakistan. Ministry of Food, Agriculture and Livestock Division, Economics Wing, Islamabad.

Gulz PA, Gupta S, Schulin R (2005). Arsenic accumulation of common plants from contaminated soils. Plant Soil. 272:337-347.

Han FX, Su Y, Monts DL, Plodinec MJ, Banin A, Triplett GE (2003). Assessment of global industrial-age anthropogenic arsenic contamination. Natur-wissenschaften 90(9):395-401.

Li C, Feng S, Shao Y, Jiang L, Lu X, Hou X (2007). Effect of arsenic on seed germination and physiological activities of wheat seedlings. J. Environ. Sci. 19:725-732.

Liu J, Zheng B, Aposhian HV, Zhou Y, Chen ML, Zhang A, Waalkes MP (2002). Chronic arsenic poisoning from burning high-arseniccontaining coal in Guizhou, China. Environ. Health Perspect. 110:119-122.
Liu X, Zhang S (2007). Intraspecific differences in effects of cocontamination of cadmium and arsenate on early seedling growth and metal uptake by wheat. J. Environ. Sci. 19:1221-1227.

Lux A, Martinka M, Vaculik M, White PJ (2011). Root responses to cadmium in the rhizosphere: a review. J. Exp. Bot. 62(1):21-37.

Mandal A, Lundh D, Nahar N, Bentol H, Bari A, Johnson-Brousseau S, Ghosh S (2011). Modeling arsenic accumulation in plants. $2^{\text {nd }}$ Int. Conf. Emerg. Appl. Info. Tech. doi: 10.1109/EAIT. 2011. P. 91.

Meharg AA, Hartley-Whitaker J (2002). Arsenic uptake and metabolism in arsenic resistant and non resistant plant species. New Phytol. 154:29-43.

Mei L, Wan X, Huang Z, Chen T, Li X, Liu Y (2012). First evidence on different transportation models of arsenic and phosphorus in arsenic hyperaccumulator Pteris vittata. Environ. Poll. $161: 1-7$.

Pigna M, Cozzolino V, Violante A, Meharg AA (2009). Influence of Phosphate on the Arsenic uptake by Wheat (Triticum durum L.) irrigated with Arsenic solutions at three different concentrations. Water Air Soil Pollut. 197:371-380.

Taiz L, Zeiger E (2006). Plant Physiology $\left(4^{\text {nd }} E d\right.$.). Sunderland, Massachusetts: Sinauer Associates, Inc. pp. 103-122.

Tanveer A, Rehman A, Javaid MM, Abbas RN, Sibtain M, Ahmad A, Zamir MS, Chaudhary KM, Aziz A (2010). Allelopathic potential of Euphorbia helioscopia L, against wheat (Triticum aestivum L.), chickpea (Cicer arietinum L.) and lentil (Lens culinaris Medic.). Turk. J. Agric. For. 34:75-81.

Tibbetts J (2000). Water world. Environ. Health Perspect. 2000. 108:6973.

Williams PN, Price AH, Raab A, Hossain SA, Feldmann J, Meharg AA (2005). Variation in arsenic speciation and concentration in paddy rice related to dietary exposure. Environ. Sci. Technol. 39:5531-5540.

Winkel L, Berg M, Amini M, Hug SJ, Johnson CA (2008). Predicting ground water arsenic contamination, in South east Asia from surface parameters. Nature Geosci. 1:536-542.

Zhang WH, Cai Y, Tu C, Ma LQ (2002). Arsenic speciation and distribution in an arsenic hyperaccumulating plant. Sci. Total Environ. 300:167-177.

Zhong L, Hu C, Tan Q, Liu J, Sun X (2011). Effects of sulfur application on sulfur and arsenic absorption by rapeseed in arsenic contaminated soil. Plant Soil Environ. 57:429-434. 